\title{
Analisis Penggunaan Strategi Ungkapan Terimakasih Oleh Penutur Asli Bahasa Jepang
}

\author{
Dyah Retno Arianti*, Silvia Nurhayati \\ Universitas Negeri Semarang \\ *dyah.arianti17@gmail.com, silvinur@unnes.ac.id
}

\begin{abstract}
Abstrak
Penelitian ini adalah penelitian tentang penggunaan strategi ungkapan terimakasih oleh penutur asli bahasa jepang. Umumnya pembelajar Bahasa Jepang mengetahui ungkapan terimakasih berupa ucapan seperti “Thankyou”, "I appreciate it”, Akan tetapi, penutur asli bahasa Jepang menyampaikan rasa terimakasih tidak hanya menggunakan ungkapan terimakasih saja tetapi menggunakan ungkapan-ungkapan lain. Tujuan dari penelitian ini adalah mendiskripsikan penggunaan strategi terimakasih yang digunakan penutur asli Bahasa Jepang. Penelitian ini menggunakan pendekatan deskriptif kuantitatif dengan angket sebagai sumber datanya. Angket dengan tipe angket terbuka disebarkan pada 65 penutur asli bahasa Jepang untuk mendapatkan jawaban yang natural dengan metode random sampling. Berdasarkan angket, dapat diketahui bahwa ketika penutur asli Bahasa Jepang berterimakasih sebagian besar menggunakan penggabungan dua strategi berterimakasih. Strategi yang paling banyak digunakan adalah strategi berterimakasih shinteki taidou no hyoumei atau ekspresi tindak psikologis.
\end{abstract}

Kata Kunci: Kansha Hyougen; Strategi Berterimakasih; Penutur Asli Bahasa Jepang

\begin{abstract}
(Title: Analysis Of Gratitude Expresion Strategy By Japanese Native Speakers). People who learn about Japanese language generally know that gratitude expressions sayings such as "Thankyou", "I appreciate it", However, Japanese native speakers convey gratitude not only using gratitude expressions but also using other expressions. The main goal of this article is to describe strategy used by Japanese people to gratitude to other people. This research uses a quantitative descriptive approach with a questionnaire as the data source. The questionnaire write in open questionnaire type was distributed to 65 Japanese native speakers to get natural answers. The questionnaire was distributed using the random sampling method. Based on the result of questionnaire, conclude that when Japanese native speakers are gratitude to other people, Japanese native speaker mostly use the combination of two thankful strategies. When Japanese native speakers are gratitude to other people, the most used strategy is the strategy is shinteki taidou no hyoumei or expressions of psychological actions.
\end{abstract}

Keywords: Kansha Hyougen; Gratitude Expresion Strategy; Japanese Native Speaker 


\section{PENDAHULUAN}

Ungkapan terimakasih merupakan salah satu ungkapan yang sering muncul dalam percakapan sehari-hari, terlebih dalam masyarakat Jepang. Dalam masyarakat Jepang, ungkapan terimakasih memainkan peranan yang sangat penting untuk membangun solidaritas antar individu dan memelihara keharmonisan sosial (Gordon, 1999).

Umumnya orang mengetahui ungkapan terimakasih bermakna meminta berterimakasih seperti pada penggunaan "Thankyou”, "I appreciate it", dan sebagainya dalam bahasa Inggris. Akan tetapi, ada ungkapan yang unik dalam bahasa Jepang yang jika ditinjau dari segi makna bermakna maaf namun kata tersebut juga dapat bermakna terimakasih dalam beberapa situasi. Salah satu contoh ungkapan tersebut adalah sumimasen.

Sakamoto (1999) dalam artikelnya yang berjudul "Arigatou to Sumimasen" mengatakan:

'Dikatakan bahwa arigatou adalah ungkapan terimakasih, sama dengan "Thank you", dan sumimasen adalah ungkapan permintan maaf, sama dengan "I am sorry". Dalam bahasa Inggris pun banyak yang menerjemahkan demikian. Orang asing yang bukan penutur asli bahasa Jepang yang berpikir sama seperti itu tidak mengerti mengapa pada saat harus mengungkapkan berterimakasih, ada orang Jepang yang bukannya mengucapkan arigatou melainkan sumimasen.'

Berdasarkan hal itu, teori tindak tutur menjadi landasan dalam penelitian ini. Hayashi (1990) mengatakan 'Tindak tutur adalah komunikasi antara manusia dengan manusia.'

Rohmadi (2004) mengatakan bahwa tindak tutur adalah produk atau hasil dari suatu kalimat dalam kondisi tertentu dan merupakan kesatuan terkecil dari komunikasi linguistik. Kemudian, Rustono (1999) menyatakan bahwa tindak tutur adalah kegiatan melakukan tindakan mengujarkan tuturan dengan maksud tertentu. Pengujaran sebuah tuturan tertentu dapat dipandang sebagai melakukan tindakan (mempengaruhi, menyuruh) disamping memang mengucapkan atau mengujarkan tuturan itu.

Menurut Searle (1969), ungkapan terimakasih masuk ke dalam kategori expressive dengan asumsi bahwa penutur mengekpresikan atau mengungkapkan perasaannya.

Robinson merasakan keanehan pada kategori expressive Searle. Jika dalam tindak berterimakasih, penutur mengungkapkan rasa bersalah, sulit membedakan seseorang itu "mengungkapkan perasaannya" (express feelings) atau "menunjukkan/mewakili perasaannya" (representing feelings). Tidak menutup kemungkinan jika dalam representatives penutur menyampaikan informasi, maka dalam tindak berterimakasih pun penutur juga bisa menyampaikan informasi tentang perasaan lain yang ada saat berterimakasih kepada seseorang. Menurutnya, inti dari berterimakasih bukanlah semata-mata mengungkapkan perasaan penutur, tetapi untuk membuat mitra tutur merasa lebih baik tentang penutur. 
Sakuma (1983) menjelaskan penggunaan ungkapan "terimakasih" dan "permintaan maaf" dari aspek psikologis pembicara.

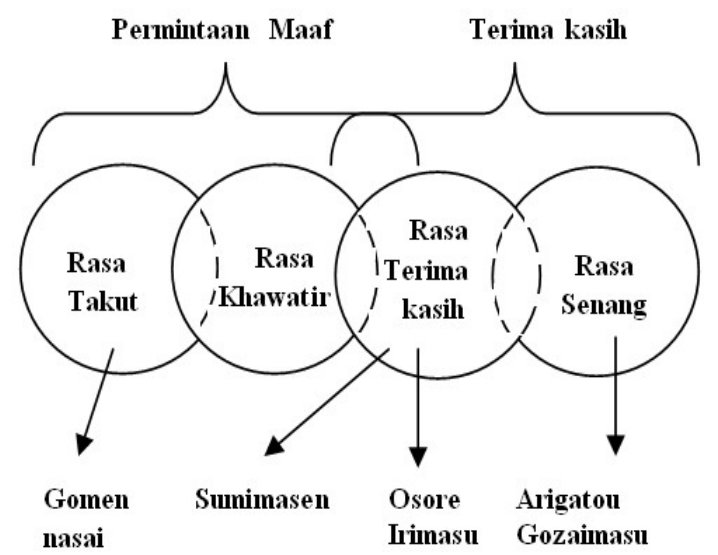

Gambar 1. Penggunaan Kansha Hyougen dan Wabi Kotoba

Menurut diagram tersebut, dari penggunaan kata "gomennasai" sampai dengan "arigatou" terdapat beragam kata lainnya yang dapat mengungkapan rasa terimakasih. Arigatou gozaimasu menunjukan rasa senang, kalimat osoreirimasu dan sumimasen digunakan untuk menggambarkan rasa terimakasih, sedangkan kata gomennasai menunjukan adanya rasa takut dalam penyampaian rasa terimakasih. Jika secara psikologis penggunaan variasi kata tersebut dikarenakan perasaan yang berbeda saat mengungkapkan rasa terimakasih. Sakuma juga mengatakan tentang perbedaan antara "terimakasih" dan "maaf". Yaitu ungkapan "terimakasih" adalah ekspresi kesenangan diri (self-directed) sedangkan ungkapan meminta maaf adalah ekspresi yang diungkapkan untuk mendorong orang lain agar berorientasi agar memiliki rasa takut ataupun khawatir.

Sementara itu, Ohashi (2000) menegaskan bahwa ungkapan terimakasih adalah sebuah sarana simbolis dari pembayaran kembali hutang budi, atau untuk mengembalikan keadaan yang tidak seimbang akibat keuntungan yang diterima penutur dari petuturnya. Arti arigatou mengesankan bahwa orang Jepang dalam menerima kebaikan dari orang lain akan merasa tidak nyaman dan terbebani dikarenakan salah satunya adalah harus mengembalikan on yang dia terima. Katakata lain yang juga mengungkapkan terimakasih. Seperti halnya kata "kinodoku", yang juga menunjuk pada beratnya menerima sesuatu. Seorang pemilik toko yang menjalankan tokonya sendiri, umumnya mengatakan secara harfiah "sumimasen", dalam hal ini artinya, "saya telah menerima on dari Anda dan di bawah pengaturan-pengaturan ekonomi modern, saya tidak pernah dapat membayar kembali kepada Anda, saya minta maaf bahwa saya ditempatkan pada posisi itu."

Penelitian tentang ungkapan terimakasih (kansha hyougen) pernah dilakukan oleh Saifudin (2004) dengan judul "Faktor Sosial Budaya Dan Kesopanan Orang Jepang Dalam Pengungkapan Tindak Tutur Terimakasih Pada Skenario Drama Televisi Beautiful Life Karya Kitagawa Eriko”. Dalam penelitian tersebut Saifudin membahas tentang tindak tutur terimakasih dan hubungannya dengan kesopanan dan faktor kebudayaan masyarakat Jepang dalam melakukan tindak tutur terimakasih. Penelitian yang dilakukan Saifudin tersebut mengambil data berupa drama televisi yang berjudul 'Beautiful Life' karya Kitagawa Eriko yang diulas menggunakan kajian pragmatik dengan tujuan untuk mengungkapkan faktor-faktor sosial budaya yang melatar belakangi pengungkapan tindak tutur terimakasih. Hasil penelitian tersebut menyimpulkan bahwa tindak tutur terimakasih adalah tindak tutur ditujukan sebagai konsekuensi 
atas manfaat atau kebaikan yang peroleh seseorang sebagai bentuk penghargaan, empati, atau rasa hutang budi yang ditujukan kepada petutur, di samping sebagai ekspresi rasa syukur dan rasa senang yang dirasakan penutur.

Pada penelitian yang dilakukan oleh Saifudin tersebut terdapat persamaan dan perbedaan dengan penelitian yang dilakukan oleh penulis. Persamaannya adalah kedua penulis sama-sama membahas mengenai tindak tutur terimakasih (kansha hyougen). Sedangkan perbedaannya adalah penelitian yang dilakukan oleh Saifudin meneliti tentang tindak tutur terimakasih secara umum, sedangkan peneliti ingin meneliti penggunaan strategi yang biasa digunakan penutur asli bahasa Jepang untuk mengungkapkan rasa terimakasih (kansha hyougen) kepada seseorang.

Kemudian sumber data yang digunakan Saifudin adalah skenario drama berjudul "Beautiful Life" yang dirasa kurang natural untuk percakapan yang dilakukan sehari hari oleh penutur bahasa Jepang, sedangkan peneliti mengambil sumber data berupa angket yang disebarkan pada penutur asli bahasa Jepang.

Miyake (1992) yang berujudul " $<$ kansha $>$ to $<$ wabi $>$ no gengo koudou: Nichiei hikaku juu nihonjin to igirisujin no daigakusei no gengochousa o chuushin ni " dalam penelitian yang dilakukan oleh Miyake tersebut membahas tentang perbedaan budaya Jepang dan Inggris dalam mengungkapkan rasa terimakasih. Dalam penelitiannya Miyake menyebarkan angket kepada 122 penutur asli bahasa Jepang dan 101 penutur asli bahasa Inggris dengan tingkatan usia dan jenis kelamin yang bervariasi. Dalam penelitian tersebut Miyake meneliti perilaku bahasa tentang ungkapan terimakasih dan ungkapan permintaan maaf secara psikologis dan cara pengungkapan bahasa yang digunakan untuk menyampaikan rasa terimakasih yang dikaitkan dengan konsep "hutang" dan "pinjaman" oleh Coulmas. Miyake berkesimpulan bahwa hal seperti rasa berhutang menjadi sangat penting untuk seseorang menentukan tingkat ekspresi bahasa yang dilakukan.

Dalam penelitian yang dilakukan oleh Miyake ini, terdapat persamaan dan perbedaan dengan penelitian yang dilakukan peneliti. Persamaan pada kedua penelitian adalah kedua peneliti sama-sama meneliti tentang ungkapan terimakasih (kansha hyougen) dan mengambil data yang menjadi dasar penelitian melalui angket yang disebarkan pada pentur asli bahasa Jepang. Namun Miyake meneliti tentang perbedaan budaya Jepang dengan Inggris dalam mengungkapkan tanda terimakasih. Sedangkan peneliti meneliti strategi yang digunakan oleh penutur asli bahasa Jepang dan penggunaannya dalam meengungkapkan rasa terimakasih.

Berkaitan tindak tutur terimakasih, Akahori (1995) berpendapat bahwa terdapat kaitan pada strategi berterimakasih dalam bahasa Jepang dan penggunaan ungkapan terimakasih dengan kondisi kesesuaian. Berdasarkan pemikiran tersebut, Akahori melakukan penelitian mengenai penggunaan ungkapan terimakasih oleh penutur asli bahasa Jepang berlandaskan strategi dari Kumatoridani (1994).

Berbeda dengan Kumatoridani (1994) Akahori, mengatur strategi secara luas untuk membahas ungkapan terima kasih dalam bahasa Jepang sehubungan dengan kerangka teori tindak tutur, sedangkan Akahori lebih mempertimbangkan penerapan pendidikan bahasa Jepang. Berdasarkan hal tersebut, Akahori merasakan perlunya pembagian strategi dengan melakukan klasifikasi kaki. 
Dengan mengacu pada teori Kumatoridani, Akahori membuat strategi berterimakasih sebagai berikut:

\section{感謝表現のストラテジー}

Kansha No Sutoratejii

Strategi Berterimakasih

\section{1. 感謝行為に関する言及}

Kanshakoui Ni Kansuru Genkyuu

Referensi Tindak Tutur Terimakasih

a. 感謝する旨の表明

Kansha suru mune no hyoumei

Pengungkapan terimakasih

e.g「ご協力に感謝する。」

b. 感謝の必要性の表明

Kansha no hitsuyousei ni hyoumei

Pengungkapan perlunya

berterimakasih

e.g「あなたには感謝しなくちゃね。」

c. 感謝の意志の表明

Kansha ishi ni hyoumei

Pengungkapan adanya rasa terimakasih

e.g「昨日のお礼を言いたくて。」

d. 感謝の方法を知らない旨を表明

Kansha no houhou wo shiranai mune wo hyoumei

Pengungkapan ketidak tahuan bagaimana berterimakasih

e.g「なんとお礼を言えばいいのか。」

2. 心的態度の表明

Shinteki Taidou No Hyoumei

Ekspresi Tindak Psikologis

a. 驚き・喜びの気持ちの表明

Odoroki $\cdot$ yorokobi no kimochi no hyoumei
Pengungkapan perasaan terkejut/ senang

e.g「いやー、うれしいわー。」

b. 感謝の気持ちを直接的表明

Kansha no kimochi wo chokusetsuteki hyoumei

Pengungkapan rasa terimakasih secara langsung

e.g「ありがとうございます。」

c. 恐縮の念や済まないという気持ち の表明

Kyoushuku no nen ya sumanai to iu kimochi no hyoumei

Pengungkapan rasa tidak enak/bersalah

e.g「すみません。」

3. 感謝の対象事物一の表明

Kansha no taishoujibutsu e no hyoumei

Pernyataan Terimakasih Pada Objek

e.g「私にまで気を使ってくれて...」

4. 負担に関する言及

Futan ni kansuru genkyuu

Pembahasan Tentang Beban

a. 相手の負担への言及

Aite no futan e no genkyuu

Pernyataan beban bagi mitra tutur

e.g「忙しいところ大変だったんじゃ いですか。」

b. 負担をかける・かけた旨への言及

Futan wo kakeru/kaketa mune e no genkyuu

Pernyataan bahwa telah/akan merepotkan

e.g「お手数をおかけします。」

c. 行為・気遣いの不必要性への言及 
Izumi, Volume 8 No 2, 2019

e-ISSN: 2502-3535 p-ISSN: 2338-249X

Tersedia online di http://ejournal.undip.ac.id/index.php/izumi

Koui/kizukai no fuhitsuyousei e no genkyuu

Pernyataan bahwa tindakkan tersebut tidak diperlukan

e.g「気使わんでもええのに。」

5. 利益に関する言及

Reiki Ni Kansuru Genkyuu

Pembahasan Tentang Keuntungan

a. 利益内容への言及

Reiki naiyou e no genkyuu

Pernyataan hal yang diuntungkan

e.g「や一、何とか間に合ったわ一。」

b. 利益の有効利用に関する言及

Reiki no yuukou riyou ni kansuru genkyuu

Pernyataan akan menggunakan keuntungan dengan efektif

e.g「ぜひ参考にさせて頂きます。」

6. 返恩の申し出し

Kae On No Moushide

Penawaran Pengembalian

e.g「今度ご飯おごるわ。」

7. プラス評価

Purasu Hyouka

Penilaian Positif

a. 相手自身へのプラス評価

Aite jishin e no purasu hyouka

Penilaian positif terhadap mitra tutur

e.g「さすがー。」

b. 関係事物へのプラス評価

Kankei jibutsu e no purasu hyouka

Penilaian positif terhadap hubungan

e.g「面白そうやな一。」

c. 念願の事物である旨の表明
Nengan no jibutsu de aru mune no hyoumei

Pernyataan terhadap keinginan

e.g「あ、これ見たいなー思ってて 几。」

8. 相手（またはそのうちの人物）が 授益者であることの明示

Aite (Mata Was Ono Uchi No Jinbutsu) Ga Juekisha De Aru Koto No Meiji Menyatakan Lawan Bicara Sebagai Penerima Keuntungan

a. 利益のもたらし手の明示

Reiki no motarashi te no hyoumei

Keuntungan adanya mitra tutur

e.g「あなたのおかげよ。」

b. 相手の存在、行為の不可欠性への 言及

Aite no sonzai, koui no fukaketsusei e no genkyuu

Esensi terhadap perbuatan dan keberadaan mitra tutur

e.g「ooさんがいなかったら間に合わ なかったよ。」

Dari beberapa kajian yang sudah disebutkan penulis menyimpulkan bahwa ungkapan terimakasih adalah ungkapan yang dilakukan penutur sebagai konsekuensi atas manfaat atau kebaikan yang ia peroleh dan sebagai bentuk penghargaan, empati, atau rasa hutang budi kepada petutur, selain sebagai ekspresi rasa syukur dan rasa senang di pihak penutur. Sehingga ungkapan ungkapan lain dapat pula digunakan sebagai ungkapan terimakasih dalam beberapa situasi tertentu. Namun, tidak dipungkiri bahwa pemakaian ungkapan lain untuk menunjukkan rasa terimakasih masih menimbulkan kesalahpahaman diantara orang asing dan pembelajar bahasa Jepang. 
Oleh karena itulah, penelitian tentang penggunaan kansha hyougen atau ungkapan terimakasih dalam beberapa situasi tutur berbeda menjadi sangat penting, untuk memperlancar komunikasi pembelajar bahasa Jepang, terutama dengan penutur asli bahasa Jepang.

Berdasarkan latar belakang tersebut, tujuan penelitian yang hendak dilakukan penulis adalah untuk mengetahui tentang penggunaan strategi yang biasa digunakan penutur asli bahasa Jepang untuk mengungkapkan rasa terimakasih (kansha hyougen) kepada seseorang.

\section{METODE}

Pelaksanaan penelitian ini dilakukan menggunakan metode deskriptif kuantitatif. suatu bentuk penelitian yang berdasarkan data yang dikumpulkan selama penelitian secara sistematis mengenai fakta-fakta dan sifat-sifat dari obyek yang diteliti, kemudian diinterpretasikan berdasarkan teori-teori dan literatur-literatur yang berhubungan.

Ungkapan-ungkapan yang digunakan penutur asli bahasa Jepang untuk mengungkapkan rasa terimakasih dalam bahasa Jepang yang kemudian diinterpretasikan berdasarkan teori-teori dan literatur-literatur yang berhubungan dengan fenomena adanya ungkapan permintaan maaf dan ungkapan lain yang bermaknakan ungkapan terimakasih bila diucapkan pada situasi tertentu.

Data yang digunakan penulis pada penelitian ini adalah ungkapan-ungkapan yang digunakan penutur asli bahasa Jepang untuk berterimakasih dalam bahasa Jepang yang terdapat dalam kuesioner atau angket yang dibagikan kepada 65 orang penutur asli bahasa Jepang yang berdomisili di Osaka.
Angket yang dibagikan kepada penutur asli bahasa Jepang adalah angket dengan tipe angket teribuka. Penulis tidak menyediakan pilihan jawaban dalam angket sehingga responden dapat menjawab dengan bebas angket yang diberikan penulis. Dengan penggunaan angket terbuka, jawaban angket dari penutur asli bahasa Jepang akan lebih natural seperti bahasa yang digunakan responden pada kesehariannya. Angket dibagikan kepada responden dengan menggunakan teknik pengambilan sampel teknik random sampling dengan menggunakan google form dan disebarkan melalui Social Networking Service (SNS). Teknik random sampling dipilih penulis sebagai teknik pengambilan sample dikarenakan penulis ingin mendapatkan data ungkapan yang digunakan penutur asli bahasa Jepang dari berbagai umur dan berbagai pekerjaan sebagai respoden kuesioner yang hendak disebarkan penulis.

Pembagian Angket dilakukan pada tanggal 14 Maret 2019 sampai dengan tanggal 20 Maret 2019. Kuesioner berupa sekumpulan pertanyaan untuk meminta jawaban responden akan hal yang diketahui serta untuk memperoleh informasi mengenai penggunaan strategi berterimakasih yang digunakan responden berdasarkan situasi yang diberikan.

Data yang didapat kemudian dianalisis dengan teknik analisis deskriptif yaitu proses pemikiran untuk mengambil pengertian-pengertian atau kesimpulan yang bersifat umum berdasarkan data atau fakta yang konkret yang bersifat khusus. Berdasarkan teori strategi berterimakasih dari Akahori (1995) data diklasifikasikan dan dirangkum untuk diambil kesimpulannya. 
Izumi, Volume 8 No 2, 2019

e-ISSN: 2502-3535 p-ISSN: 2338-249X

Tersedia online di http://ejournal.undip.ac.id/index.php/izumi

PEMBAHASAN DAN HASIL

Berdasarkan hasil klasifikasi menggunakan teori strategi berterimakasih dari Akahori (1995) data yang diperoleh mengenai penggunaan strategi berterimakasih berdasarkan angket yang disebarkan peneliti kepada 65 orang responden penutur asli bahasa Jepang. Berikut hasil penelitian yang dapat dilihat pada tabel 1 .

Tabel 1

Strategi Berterimakasih Berdasarkan Lawan Bicara

\begin{tabular}{|c|c|c|c|c|c|c|c|c|c|}
\hline $\begin{array}{l}\text { Strategi } \\
\text { Berterimakasih } \\
\text { / Lawan Bicara }\end{array}$ & Dosen & $\begin{array}{l}\text { Orang } \\
\text { Tidak } \\
\text { Dikenal }\end{array}$ & Atasan & Dosen & Atasan & Teman & Teman & $\begin{array}{l}\text { Pelayan } \\
\text { Restoran }\end{array}$ & Jumlah \\
\hline $\begin{array}{l}\text { Referensi } \\
\text { Tindak Tutur } \\
\text { Terimakasih }\end{array}$ & 0 & 0 & 0 & 0 & 0 & 4.44 & 7.96 & 0 & 12.40 \\
\hline $\begin{array}{l}\text { Ekspresi Tindak } \\
\text { Psikologis }\end{array}$ & 76.47 & 89.04 & 51.59 & 63.83 & 75 & 72.22 & 52.21 & 73.86 & 554.22 \\
\hline $\begin{array}{l}\text { Pernyataan } \\
\text { Terimakasih } \\
\text { Pada Objek }\end{array}$ & 2.35 & 2.74 & 0 & 0 & 0 & 0 & 0 & 0 & 5.09 \\
\hline $\begin{array}{l}\text { Pembahasan } \\
\text { tentang Beban }\end{array}$ & 8.24 & 4.11 & 0 & 19.79 & 20 & 2.22 & 1.77 & 26.14 & 82.27 \\
\hline $\begin{array}{l}\text { Pembahasan } \\
\text { Tentang } \\
\text { Keuntungan }\end{array}$ & 10.59 & 4.11 & 3.17 & 9.38 & 5 & 16.67 & 8.85 & 0 & 57.77 \\
\hline $\begin{array}{l}\text { Penawaran } \\
\text { Pengembalian }\end{array}$ & 0 & 0 & 0 & 0 & 0 & 4.44 & 29.20 & 0 & 33.64 \\
\hline Penilaian Positif & 2.35 & 0 & 45.24 & 8.33 & 0 & 0 & 0 & 0 & 55.92 \\
\hline $\begin{array}{l}\text { Menyatakan } \\
\text { Lawan Bicara } \\
\text { Sebagai } \\
\text { Penerima } \\
\text { Keuntungan }\end{array}$ & 0 & 0 & 0 & 0 & 0 & 0 & 0 & 0 & 0 \\
\hline
\end{tabular}

Keterangan: angka pada tabel dalam persen (\%)

Tabel 1, merupakan tabel hasil penyebaran angket pada 65 orang penutur asli Bahasa Jepang berdasarkan lawan bicara pada contoh situasi yang diberikan oleh penulis.

Berdasarkan tabel 1, dapat diketahui bahwa ketika penutur asli bahasa mengungkapkan rasa terimakasihnya, penggunaan strategi shinteki taidou no hyoumei atau strategi ekspresi tindak psikologis sangat mendominasi pada setiap situasi. Penggunaan strategi shinteki taidou no hyoumei ini sendiri melebihi 50\% pada setiap situasi pada angket. Contoh penggunaannya dapat dilihat berdasarkan 3 golongan dalam strategi shinteki taidou no hyoumei. Yaitu odoroki/yorokobi no kimochi no hyoumei (pengungkapan perasaan senang dan atau terkejut), kansha no kimochi chokusetsu hyoumei (pengungkapan terimakasih secara langsung) dan kyoushuku no nen ya sumanai to iu kimochi no hyoumei (perasaan tidak enak ataupun bersalah kepada mitra tutur). Strategi selanjutnya yang banyak digunakan penutur asli bahasa Jepang adalah strategi futan ni kansuru genkyuu (pembahasan tentang beban) sebanyak $82.27 \%$. strategi ini digolongkan menjadi dua, yaitu aite no futan $e$ no genkyuu (pernyataan beban bagi mitra tutur) 
dan futan wo kakeru/kaketa mune e no genkyuu (pernyataan bahwa telah/akan merepotkan). Contoh kalimat yang biasanya digunakan adalah "meiwakukakete, sumimasen" ataupun mendou wo okake shimashita".

Penggunaannya sendiri tidak seperti sinteki taidou no hyoumei yang mendominasi disetiap situasi, penggunaan strategi futan ni kansuru genkyuu sangat berkaitan dengan situasi dan lawan bicara. Dalam beberapa situasi penggunaanya cukup mendominasi untuk menyatakan rasa terimakasihnya, namun ada pula situasi dimana strategi ini tidak digunakan untuk pengungkapan rasa terimakasih penutur asli bahasa Jepang.

Sama halnya dengan strategi futan ni kasnuru genkyuu,Strategi selanjutnya yang banyak digunakan penutur asli bahasa Jepang adalah strategi rieki ni kansuru genkyuu (pembahasan tentang keuntungan) sebanyak $57.77 \%$ yang mana penggunaan strategi ini terdapat hampir pada semua situasi namun tidak terlalu banyak digunakan. Contoh kalimat yang biasanya digunakan adalah "arigatou gozaimasu. Tasukarimasu" ataupun "hontouni ii ? chotto kariru ne!".

Strategi selanjutnya yang banyak digunakan penutur asli bahasa Jepang adalah strategi purasu hyouka (penilaian positif) yang digunakan sebanyak $55.92 \%$. Berbeda dengan strategi-strategi sebelumnya, penggunaan strategi purasu hyouka ini hanya digunakan penutur asli bahasa Jepang pada situasi tertentu. Namun penggunaannya cukup mendominasi ketika strategi ini digunakan. Contoh kalimat yang biasanya digunakan adalah "arigatou gozaimasu, ganbarimasu!"'ataupun dengan pernyataan seperti "gochosou sama desu".

Strategi selanjutnya yang banyak digunakan penutur asli bahasa Jepang adalah strategi henon no moushide (penawaran pengembalian) yang digunakan sebanyak $33.64 \%$. sama halnya dengan strategi purasu hyouka, strategi henon no moushi de ini hanya digunakan penutur asli bahasa Jepang pada situasi tertentu. Namun penggunaannya cukup mendominasi ketika strategi ini digunakan. Contoh kalimat yang biasanya digunakan adalah "tsugi au toki kaesu yo!"ataupun dengan pernyataan seperti "gomen, chotto karirune, kondo ogoru yo!".

Strategi selanjutnya yang digunakan penutur asli bahasa Jepang adalah strategi Kanshakoui Ni Kansuru Genkyuu (referensi tindak tutur terimakasih) yang digunakan hanya sebanyak $12.40 \%$ dan strategi Kansha no taishoujibutsu e no hyoumei (pernyataan terimakasih pada objek) yang digunakan hanya sebanyak 5.09\%. Penggunaannya sendiri sangat jarang digunakan penutur asli Bahasa Jepang untuk mengungkapkan rasa terimakasih. Namun, ada pula yang menggunakan kedua strategi berterimakasih ini dalam situasi yang di sediakan peneliti dalam angket yang disebarkan.

Penggunaanya strategi Kanshakoui Ni Kansuru Genkyuu (referensi tindak tutur terimakasih) ditunjukan dengan penggunaan kalimat seperti "maji de kansha!" ataupun "nanto rei wo ieba ii noka". Sedangkan strategi Kansha no taishoujibutsu e no hyoumei (pernyataan terimakasih pada objek) ditunjukan dengan penggunaan kalimat seperti " $k i$ wo tsukawanaide kudasai”.

Berdasarkan hal tersebut, dapat diketahui bahwa penggunaan strategi berterimakasih, sangat berkaitan dengan 
situasi dan lawan bicara. Namun, pada situasi apapun dan dengan siapapun penutur berbicara, penutur asli bahasa Jepang hampir selalu menggunakan strategi shinteki taidou no hyoumei atau ekspresi tindak psikologis.

Sedangkan penggunaan strategi berterimakasih sendiri dapat dilihat pada tabel 2 sebagai berikut.

Tabel 2

Penggunaan Strategi Berterimakasih

\begin{tabular}{lccc}
\hline $\begin{array}{l}\text { Lawan } \\
\text { Bicara/Strategi }\end{array}$ & 1 Strategi & 2 Strategi & 3 Strategi \\
\hline Dosen & 8 & 13 & 2 \\
$\begin{array}{l}\text { Orang Tidak } \\
\text { Dikenal }\end{array}$ & 8 & 7 & 0 \\
Atasan & 2 & 6 & 1 \\
Dosen & 13 & 16 & 3 \\
Atasan & 9 & 8 & 0 \\
Teman & 12 & 8 & 0 \\
Teman & 9 & 12 & 6 \\
Pelayan Restoran & 11 & 6 & 0 \\
\hline Jumlah & 72 & 76 & 12
\end{tabular}

Tabel 2 merupakan tabel penggunaan strategi yang biasa dilakukan penutur asli Bahasa Jepang dalam mengungkapkan rasa terimakasihnya.

Berdasarkan tabel 2, dapat diketahui bahwa ketika penutur asli bahasa mengungkapkan rasa terimakasihnya, penutur asli bahasa Jepang menggunakan satu strategi sampai dengan tiga strategi berterimakasih. Contohnya dengan

\section{“Tasukarimasu” \\ (Reiki ni kansuru genkyuu)}

Penggunaan kata tersebut untuk berterimakasih kepada seseorang ditunjukan hanya dengan satu kata dan satu strategi yaitu reiki ni kansuru genkyuu (pernyataan tentang keuntungan). namun penggunaan dua kata untuk mengungkapkan rasa terimakasih dengan strategi yang sama digolongkan menjadi satu strategi. contohnya

$\begin{array}{ll}\stackrel{\text { moushiwakenai }}{\text { desu, }} & \frac{\text { Arigatou }}{\text { gozaimasu" }} \\ \begin{array}{ll}\text { (Shinteki taidou no } \\ \text { hyoumei) }\end{array} & \begin{array}{l}\text { (Shinteki taidou } \\ \text { no hyoumei) }\end{array}\end{array}$

Berdasarkan tabel 2, dapat diketahui bahwa penutur asli bahasa Jepang paling banyak menggunakan dua strategi dalam mengungkapkan rasa terimakasihnya. Contoh penggunaannya adalah seperti berikut:

"Meiwaku kakete, Sumimasen!"

(Futan ni kansuru (Shinteki taidou genkyu) no hyoumei)

Berdasarkan penggabungan dua strategi berterimakasih, yaitu strategi futan ni kansuru genkyuu (pembahasan tentang beban) dan strategi shinteki taidou no hyoumei (ekspresi tindak psikologis) pada satu kalimat untuk menyatakan rasa terimakasih.

Kemudian penggabungan tiga strategi strategi dilakukan pula oleh penutur Bahasa Jepang untuk berterimakasih pada situasi tertentu. Contohnya

"Sumimasen, gochisousama desu.

(Shinteki taidou no (purasuhyouka) hyoumei)

Kansha shimasu"

(kansha koi ni kansuru genkyuu)

Berdasarkan penggabungan tiga strategi berterimakasih, yaitu strategi strategi shinteki taidou no hyoumei (ekspresi tindak psikologis), purasu hyouka (penilaian positif) dan strategi kansha koi ni kansuru genkyuu (referensi tindak tutur terimakasih) pada satu kalimat untuk menyatakan rasa terimakasih.

Berdasarkan penggabungan strategi yang digunakan penutur asli bahsa Jepang 
untuk berterimakasih, dapat di simpulkan bahwa ketika penutur asli Jepang berterimakasih kepada seseorang, tidak hanya terdapat rasa terimakasih, namun juga terdapat terasaan yang lain seperti halnya contoh diatas, yaitu terdapat perasaan telah membebani mitra tutur dengan penggunaan kata "meiwaku kakete" serta perasaan tidak enak dan bersalah kepada mitra tutur yang dapat dilihat dengan penggunaan kata kata "sumimasen" dalam pengungkapan rasa terimakasih.

\section{PENUTUP}

Berdasarkan hasil angket yang disebarkan peneliti kepada responden penutur asli bahasa Jepang, dapat disimpulkan bahwa penggunaan strategi berterimakasih yang digunakan penutur asli bahasa Jepang dalam mengungkapkan rasa terimakasihnya didominasi oleh strategi shinteki taidou no hyoumei (Ekspresi tindak psikologis) dimana penggunaannya disemua contoh situasi melebihi 50\%. Ekspresi tindak psikologis ini mencakup odoroki/yorokobi no kimochi no hyoumei (pengungkapan perasaan senang dan atau terkejut) seperti pengungkapan dengan menggunakan kata "a!", "wa " atau dengan kata yang mengungkapkan perasaan "ureshii" dan lain sebagainya. Kansha no kimochi chokusetsu teki hyoumei (pengungkapan rasa terimakasih secara langsung) dengan ucapan "arigatou gozaimasu" ataupun "sankyuu" secara langsung. Shinteki taidou no hyoumei (Ekspresi tindak psikologis) juga mencakup kyoushuku no nen ya sumanai to iu kimochi no hyoumei (perasaan tidak enak ataupun bersalah kepada mitra tutur) yang mendasari penggunaan kata permintaan maaf seperti "sumimasen", "warui" dan "moushiwakenai" dalam pengungkapan rasa terimakasih oleh penutur asli bahasa Jepang.
Penggunaan strategi yang digunakan, responden mengungkapkan bahwa pengungkapan ungkapan terimakasih, ungkapan yang digunakan penutur asli bahasa Jepang paling banyak diungkapkan dengan menggunakan dua strategi dalam satu kalimat. Hal tersebut menandakan bahwa penyampaian rasa terimakasih bisa saja diiringi dengan perasaan lain pada saat pengungkapannya.

\section{DAFTAR PUSTAKA}

Akahori, Yukiko. (1995). Nihongo Bogowasha No Kansha Hyougen: Sutoratejii No Shurui To Sono Tsukai Bun Wake Wo Chuushin Ni. Osaka: OsakaUniversity.

Gordon, Bill. (1999). Analysis of Gratitude Speech Act.

Kumatoridani T. (1994). Hatsuwa Koui Toshite no Kansha - Tekisetsusei Jouken Hyougen Sutoratejii- Danwa Kinou. Nihongogaku

Miyake, Kazuko. (1992). <kansha $>$ to $<$ wabi> no gengo koudou: Nichiei hikaku juu nihonjin to igirisujin no daigakusei no gengochousa o chuushin ni.

Ohashi, Jun. (2000). Orei and the Speech Act of Thanking. University of Melbourne.

Robinson, Robinson. (2006). Introducting Performative Pragmatics. New York: Routledg.

Rohmadi, Muhammad. (2004). Pragmatik Teori dan Analisis. Yogyakarta: Lingkar Media.

Rustono. (1999). Pokok-Pokok Pragmatik. Semarang: IKIP Semarang Press. 
Izumi, Volume 8 No 2, 2019

e-ISSN: 2502-3535 p-ISSN: 2338-249X

Tersedia online di http://ejournal.undip.ac.id/index.php/izumi

Saifudin, Akhmad. (2004). Tesis " Faktor Sosial Budaya Dan Kesopanan Orang Jepang Dalam Pengungkapan Tindak Tutur Terimakasih Pada Skenario Drama Televisi Beautiful Life Karya Kitagawa Eriko"

Sakamoto, Megumi. (1999). Arigatou to Sumimasen. Kirin (no. 8). Shinagawa Daigaku Keiei Gakubu Jyuunana Seiki Bungaku Kenkyuu Kai.
Sakuma, Katsuhiko. (1983). Kansha to wabi "hanashi kotoba no hyougen" kouza nihongo no hyougen Mizutani Oosamu hen.

Searle, John R. (1969). Speech Acts. An Essay in the Philosophy of Language. Cambridge: Cambridge University Press. 